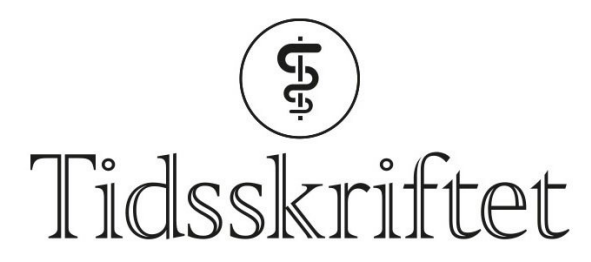

DEN NORSKE LEGEFORENING

\title{
En oppskrift på kefir fra 1887
}

TIDLIGERE I TIDSSKRIFTET

JULIE DIDRIKSEN

Tidsskriftet

Kefir er en type syrnet melk som har sine røtter fra området rundt fjellet Elbrus i Kaukasus. Den har lengre holdbarhet enn søtmelk, og den tykke konsistensen kommer av at melkeproteinene folder seg ut og fester seg til hverandre når melken varmebehandles. Når temperaturen senkes igjen, tilsettes etter hvert kefirkorn, som inneholder flere bakterietyper og gjær. Under følger en oppskrift Tidsskriftet hadde på trykk i nr. 12/1887 (Tidsskr Prakt Med 1887; 7: 205-6).

\section{Kefir.}

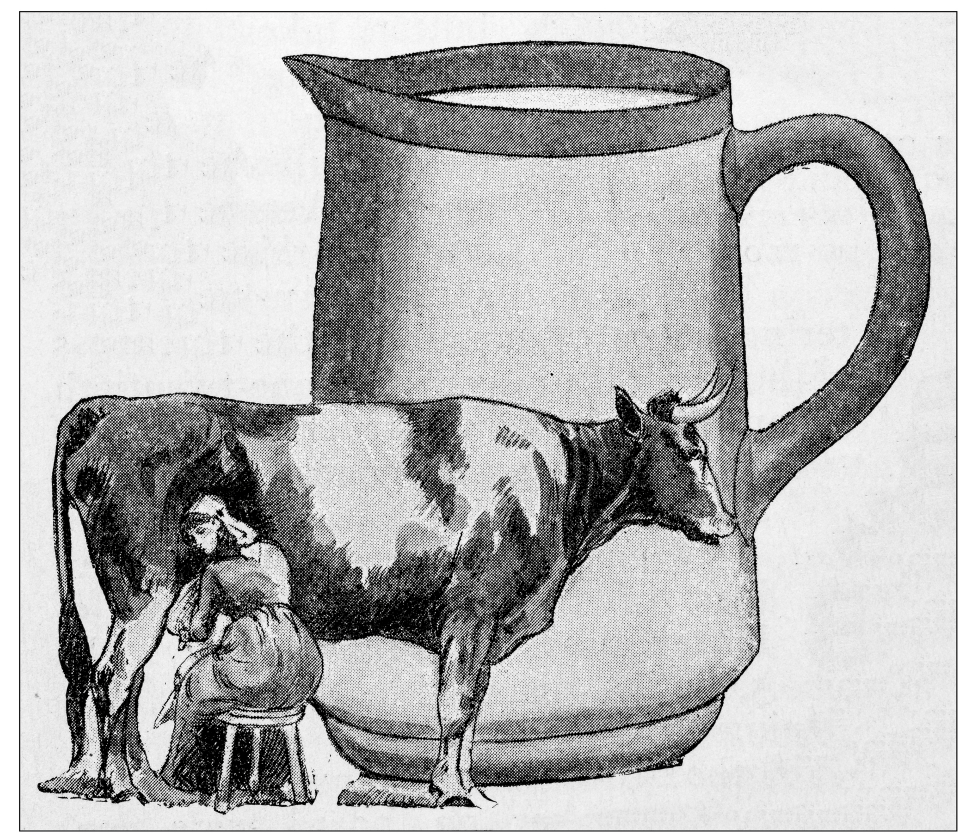

Illustrasjon: ilbusca/iStock

5 Gram af Knollerne (Soppen, Diaspora Caucasica Kern) er nok til en Liter Melk. Man skyller dem i lunkent Vand før Benyttelsen. De er i tør Tilstand gule, men bliver efter nogle Ganges Brug melkehvide.

Hver Aften koges en Liter skummet Melk, fordeles i to Kar og bedækkes mod Støv. Naar den ene Halvdel er afkjølet til $+4 \mathrm{O}^{\circ} \mathrm{C}$., bringes Kefirknollerne op i den, og det staar Natten over. Næste Morgen siles Knollerne fra, den afsilede Melk hældes paa rene Flasker, der henstaar paa et middelsvarmt Sted et Døgn, hvorefter Kefiren er færdig til at drikkes. En saadan 
Portion drikkes op i Løbet af Dagen, og der sættes en ny i Arbeide hver Aften. Anden Melk maa ikke nydes ved Siden af. Kefirknollerne kan benyttes i flere Maaneder, men maa mellem hver Gang skylles i flere Vand og tørres lidt.

God Kefir er af sød, lidt emmen Smag

Af særlig Vigtighed er baade det første Opkog, hvorved de Melken iboende Gjærsoppe og Spaltsoppe tilintetgjøres, at Flaskerne er rene, og at Melken holdes bedækket under Gjæringen, saa ingen “vilde” Gjærarter kan trænge sig ind. Temperaturen maa den første Nat ikke være for lav og i det følgende Døgn ikke for høi. I sidste Tilfælde vil Kefiren let blive for tyk, d. v. s. Kaseinkoaglet løber sammen i stedet for at bevare den finfnokkede Tilstand, der bør have.

God Kefir er af sød, lidt emmen Smag. Enkelte Syge taaler den bedre end Melk, den forbedrer deres Madlyst og under velordnede Forhold iøvrigt tiltager de i Kræfter og Legemsvægt.

Enkelte Syge taaler den bedre end Melk

Kefirknoller fra Gehe \& Co. kan faaes paa Elefantapoteket i Kristiania. Ovenbeskrevne Metode er i et Par Maaneder prøvet her paa Diakonissehuset, hvor en Patient har gjort gode Fremskridt under Bruken.

$W$.

Publisert: 23. september 2019. Tidsskr Nor Legeforen. DOI: 10.4045/tidsskr.19.0156

(C) Tidsskrift for Den norske legeforening 2020. Lastet ned fra tidsskriftet.no 